\title{
Beyond Post-Downsizing Organisational Injustice and Counterproductive Work Behaviours: Antecedents and Consequences of Learnt Helplessness
}

\author{
Susan P. Chen ${ }^{1} \&$ Reidar J. Mykletun ${ }^{2}$ \\ ${ }^{1}$ Faculty of Social Science, University of Stavanger, Norway \\ ${ }^{2}$ Norwegian School of Hotel Management, Faculty of Social Sciences, University of Stavanger, Norway \\ Correspondence: Susan P. Chen, University of Stavanger, 4068 Stavanger, Norway. Tel: 659-159-0413. E-mail: \\ susan.ps.chen@gmail.com
}

Received: January 26, 2015

Accepted: April 20, 2015

Online Published: May 25, 2015

doi:10.5539/ijbm.v10n6p1

URL: http://dx.doi.org/10.5539/ijbm.v10n6p1

\begin{abstract}
The overall objective of this study was to explore perceived organisational injustice through the lens of learnt helplessness in a Norwegian post-merger case study focusing on an ageing knowledge-based workforce. The case describes a lucrative large-scale early retirement organisational downsizing deployed only in the headquarters, located in Norway, but not offered across country subsidiaries. This qualitative research collected data from 28 semi-structured face-to-face interviews and other observations.

This study was based on the assumption that organisational injustice would prevail with observed counter-productive workplace behaviours (CWBs). Three research questions were formulated: 1) Does perceived organisational injustice always lead to the expected CWB? 2) To what degree does learnt helplessness function as a buffer against the expected CWB resulting from perceived organisational injustice? 3) What are the antecedents and consequences of learnt helplessness?

A key contribution of this study is to provide a unique case where injustice does not always lead to the predicted negative organisational outcomes of CWBs under the conditions of learnt helplessness. The case illustrates that organisational culture is the antecedent of learnt helplessness, which in turn, has buffering effects against the predicted CWBs.
\end{abstract}

Keywords: organisational justice, organisational culture, counterproductive workplace behaviours, learnt helplessness, antecedents, downsizing

\section{Introduction}

In the current turbulent business environment, utilising downsizing to improve firm performance and competitiveness is a common strategy. Organisational downsizing is broadly defined as a set of management activities aimed at improving organisational efficiency, productivity and competitiveness (Freeman \& Cameron, 1993). It is often perceived as a defensive rather than a proactive organisational strategy (Rehman \& Naeem, 2012) to realign organisational challenges. However, the success of downsizing is often questionable because intended positive economic effects such as cost savings often resulted in opposite and controversial negative economic outcomes, where the opportunity cost can be measured in both tangible and intangible ways (Dolan, Belout, \& Balkin, 2000). Research reveals that organisations often enjoy an initial increase in productivity immediately following downsizing because the remaining employees work harder and more competitively in an attempt to keep their jobs (Appelbaum, Delage, Labib, \& Gault, 1997). However, this increase in productivity is often short-lived. Therefore, some authors coined the word 'dumbsizing' to describe these activities (Wilkinson, 2005).

The effects of organisational downsizing on survivors, known as survivor syndrome, have also been widely researched (Appelbaum \& Donia, 2000; Noer, 1993). Also known as survivor's guilt, the phenomenon refers to the negative effects of downsizing on those who remain with the company, resulting in complex emotions such as guilt, anger and/or relief, which are often exhibited and manifested through undesirable behaviours, after being retained following post-merger downsizing activities (Appelbaum \& Donia, 2000; Gutknecht \& Keys, 
1993). Research shows that survivors have lower job satisfaction, lower organisational commitment, and more frequent sick leave after downsizing (Brockner, 1988; Brockner, Grover, Reed, DeWitt, \& O'Mallet, 1987). Survivors may then engage in counter-organisational citizenship behaviours (Arshad \& Sparrow, 2010; Colquitt, Conlon, Porter, \& Wessom, 2001). However, inconsistent findings have been reported, and some studies suggest that downsizing has little effect on the sickness absences of surviving employees (Østhus \& Mastekaasa, 2010).

This study explored the reactions of employees in a large Norwegian company during a post-merger downsizing that offered lucrative early retirement packages only to employees of the Norwegian main office and not to those of subsidiaries across the country. The reactions studied were employees' perceptions of organisational injustice and the potential buffering effect of learnt helplessness on predicted counterproductive workplace behaviours (CWBs). In this study, organisational justice theory and learnt helplessness offered the frameworks to explore and understand employees' feelings and emotions as responses to unequal treatment in an international organisation. Organisational justice theory integrates the outcomes of organisational change with the methods used to achieve it and the perceptions of the treatments of those who are affected. Previous research has focused little on learnt helplessness relative to organisational culture and justice perspectives. This case study has the potential to provide further insights into organisational injustice and downsizing by redrawing the generalisation that employees tend to react negatively by exhibiting CWBs when perceiving organisational injustice (Appelbaum, 1997; Berry, Carpenter, \& Barratt, 2012).

This paper explores three research questions: 1) Does perceived organisational injustice always lead to the expected CWB? 2) To what degree does learnt helplessness function as a buffer against expected CWB resulting from perceived organisational injustice? 3) What are the antecedents and consequences of learnt helplessness? We conclude with a discussion of implications and a brief reflection on the limitations of this study and directions for future research.

\section{Conceptualizing Organisational Justice and Counterproductive Work Behaviours}

Downsizing is commonly used as a context for studying justice because it is during this time that a breach of justice is often perceived. Research on moderators that may influence the effectiveness of employee downsizing has found that employee performance after downsizing is closely related to the way in which it was implemented, not whether it should have been done (Cascio, 2002; Chadwick, Hunter, \& Walston, 2004; Kim, Triandis, Kfiitibai, Choi, \& Yoon, 1994).

Justice is socially constructed (Cropanzano \& Greenberg, 1997). Therefore, organisational justice theory focuses on employees' perceptions of fairness of the treatment they themselves have encountered as well as the treatment of others within the organisation. Although the existing literature has offered multiple conceptualisations of justice in the past decade (Colquitt, Conlon, Porter, Wessom, \& Ng, 2001; Moorman, 1991), this study adopts the justice construct as defined by Greenberg (1993), considering three types of organisational justice perspectives: distributive justice, procedural justice and interactional justice (Greenberg, 1987; 1993). The first two refer to the status aspects of justice, whilst the last focuses on the social aspects. Greenberg (1993) proposed clear distinctions between structural and social determinants of justice; the former refer to justice sought by focusing on environmental contexts within which interaction occurs, and the latter focus on the treatment of individuals.

Studies of organisational justice conducted prior to 1975 were primarily concerned with distributive justice (Colquitt et al., 2001). This refers to perceived fairness of the balance between input and relative outcomes compared to others using the social exchange framework to evaluate fairness (Adams, 1965). From this perspective, individuals evaluate justice by assessing their input (e.g. work experiences, intelligence and education) in comparison to one's outcome and in comparison to others' inputs and relative outcomes. This is also referred to as the equity theory, suggesting that conditions of unfairness create negative tension within an individual, who will therefore seek to find ways to resolve the tension (Adams, 1965). Previous research has also suggested that the perception of distributive justice is more strongly related to satisfaction with, and distribution of, wages (Folger \& Konovsky, 1989).

Procedural justice refers to how the organisation arrives at decisions. This depends on the consistencies of processes and the extent of influence and control of the outcome one perceives to have in a process. Research suggests that individuals are willing to give up control over the outcomes if they perceive that they have control over the procedures used to reached the final decision (Thibaut \& Walker, 1975). Others suggest that a procedure can be considered fair only if (a) it is applied consistently across people and across time, (b) it is free of biases, (c) it uses accurate information to make the decision, (d) it has mechanisms to correct incorrect decisions, (e) it conforms to ethical and moral standards and (f) it ensures that all groups affected by the decision have been considered (Leventhal, 1980). Within organisational contexts, dispute resolution procedures and organisational 
downsizing processes have been the most frequently researched topics, and they are strongly related to organisational commitment and trust in the supervisor (Folger \& Konovsky, 1989). In unionised contexts, workplace justice is established through grievance procedures, and it is highly correlated with employees' perceptions of justice (Gordon \& Fryxell, 1993).

Interactional justice has two distinct components: interactional and informational (Greenberg, 1993). Interactional justice focuses on the importance of quality in the interpersonal treatment that one receives when changes or processes are being implemented (Bies \& Moag, 1986). It is concerned with social sensitivity, or the extent to which people believe that they are being treated with dignity and respect (Greenberg \& Baron, 2003). In contrast, informational justice refers to the perceived fairness of explanations for procedures and distributions (Greenberg, 1993). The quality of information received is a key antecedent of interpersonal justice (Kernan \& Hanges, 2002). Negative outcomes will be considered fair if the decision is conveyed with accuracy, comprehensiveness and the right timing (Furnham \& Siegel, 2012). For the purpose of this research, a breach in distributive justice is expected to emerge because the desirable early retirement package was not offered at all locations. Additionally, breach of procedural and interactional justice may also be observed, depending on the way the decisions surrounding early retirement packages were perceived and communicated.

Organisational injustice is one of the common explanations of CWBs to re-establish justice (Furnham \& Siegel, 2012). Also referred to in the literature as organisational deviance behaviour, CWB refers to voluntary behaviour that violates significant organisational norms and threatens the well-being of the organisation and/or its members. Such behaviour may manifest itself through frequent absenteeism, harassment, theft and withdrawal (Robinson \& Bennett, 1995). Workplace deviance behaviours can be broadly categorised into property deviance and production deviance. Property deviance refers to damaging, stealing and misusing company property, while production deviance refers to absenteeism, sick leave and sloppy work (Hollinger \& Clark, 1982). Two additional categories of deviance suggested by Robinson and Bennett (1995) are political deviance and personal aggression. Political deviance refers to engaging in social behaviours that put others at a personal or political disadvantage, (e.g. ramous and favouritism), while personal aggression is defined as behaving in an aggressive manner toward co-workers. Therefore, organisational justice became an important concept in the prediction of CWBs. Research also concluded that employee perceptions of both distributive and procedural justice would influence the level of OCBs (Moorman, 1991; Organ \& Moorman, 1993). Therefore, if employees perceive that the outcomes of their evaluations and the processes by which those outcomes are allocated are fair, they will likely reciprocate by performing positive extra-role behaviours that benefit the organisation. The concept of CWB is central to this study. With injustice, as perceived in the study, it is expected that an increase in turnover and certain self-reported CWBs as attempts to balance the injustice will be observed.

Research indicates that a lack of fairness leads to dissatisfaction, prompting individuals to withhold discretionary behaviours and limit their contributions to the organisation (Organ, 1990). Moreover, some researchers (Organ \& Paine, 1999) suggest that perceived injustice will definitely prompt CWBs, but perceived justice may not always lead to organisational citizenship behaviours (OCBs). Counterproductive workplace behaviours are often discussed in the context of OCBs, which are discretionary and extra-role behaviours that contribute positively to the functioning of the organisation, and they are not directly or explicitly recognised by the formal reward system (Organ, 1988). However, the lack of OCBs does not imply the presence of CWBs. In other words, employees can choose not to make an extra effort in their job, but this does not mean that the employee will then engage in CWBs.

Counterproductive workplace behaviours can vary along a continuum of severity and can be distinguished between interpersonal and organisational levels. Interpersonal CWBs influence an individual negatively (e.g., bullying a co-worker), whist organisational level CWBs influence the overall organisation (e.g., theft and absenteeism; Robinson \& Bennett, 1995). Most studies of CWBs assess one or two overall dimensions: CWB-I (individual) and CWB-O (organisational; Smith, Organ, \& Near, 1983), which might obscure relationships between potential antecedents of CWBs and specific forms of behaviours (Spector, Fox, Penney, Bruursema, Goh, \& Kessler, 2005). This prompted conceptualisation of CWBs in five dimensions: abuse toward others, production deviance, sabotage, theft and withdrawal (Spector et al., 2005). The five dimensions allow for a more detailed assessment of the antecedents of CWBs, where abuse and sabotage were mostly strongly related to anger and stress, theft was unrelated to emotions, and withdrawal was associated with boredom or perceived injustice (Spector et al., 2005). 


\section{Learnt Helplessness}

\subsection{Leant Helplessness in Organisational Settings}

Several studies have focused on the moderators of, or, buffers against CWBs. Buffering effects often reflect a capacity to absorb negative shocks, due to the likes of unforeseen and undesirable organisational changes, before engaging in undesirable organisational behaviours (Sutcliffe \& Vogus, 2003). Learnt helpless, a buffer against predicted CWBs, is relevant to this study. Moreover, organisational culture is expected to be a dimension that influences learnt helplessness.

Learnt helplessness refers to a state wherein individuals are faced with prolonged undesirable situations and subsequently, they give up the belief that they can escape from the undesirable situation, developing passive or palliative coping strategies instead (Seligman, 1975). It refers to the state of mind or condition in which a human being or an animal has learnt to behave helplessly, even when the undesirable and/or harmful situation is removed, providing the opportunity for one to help themselves. The learnt helplessness theory explains how individuals stop believing that one's actions will have a predictable and desirable outcome. Because the theory suggests that this helplessness is learnt, it is possible that such helplessness can also be unlearnt or, with early interventions, be prevented. In the organisational context, this is applicable relative to perceived control and largely, employee empowerment. This, then, was termed 'learnt optimism' (Seligman, 1975). Although many individual- and group-level studies have been conducted on learnt helplessness, only a few focused on the organisational contexts (Silvet, 2013).

Abramson, Seligman and Teasdale (1978) further conceptualised the model of learned helplessness based on attribution theory. Attribution theory suggests that people make causal explanations for observed events and behaviours, affecting their actions and outcomes differently (Heider, 1958). These causal attributions have a powerful effect on the feelings, plans and well-being of employees. The model provides a framework by which attributions made by persons can be classified so that an understanding of the state of learned helplessness can be achieved. The model explains the role of attributing depression and vulnerability situations in learned helplessness. Various factors, including organisational culture dimensions and personal factors, were shown to predict learned helplessness attributions (Saxena \& Shah, 2008).

In connection with learnt helplessness, the concept of self-justification is often explored in reflection of learnt optimism, where one can learn to exercise positive psychology in dealing with undesirable situations (Seligman, 1992). Self-justification refers to situations in which individuals face undesirable negative consequences of behaviours. The individuals may distort the negative consequences to give a more positive valence to the outcomes (Staw, 1976). Such self-justification helps individuals rationalise and psychologically defend themselves against adverse consequences (Staw, 1976). When individuals have experiences that are inconsistent with their expectations, they engage in various compensatory efforts, which can manifest themselves in behaviours ranging from the 'high level' attitudinal dissonance to 'lower level' colour/word mismatch (Proulx, Inzlicht, \& Harmon-Jones, 2012). Early research often associated this self-justification with decision-making processes within the organisations, where individuals were committed to bad decisions or errors by justifying to themselves and others that the decision or error was really the correct one in the long run (Staw, 1976). However, recent research seeks to support a multi-discipline approach, utilising religion and learning theories, among others, to study such behaviour dissonance (Mason, Boscolo, Tornatora, \& Ronconi, 2013; Oziev \& Fontaine, 2013).

\subsection{Antecedents of Learnt Helplessness: Organisational Culture and Trust}

An organisation's ability to develop and build a trusting organisational culture is important for the sustainability of the organisation (Barney, 1991), whilst learnt helplessness is negatively associated with the notion of organisational trust (Kundi et al., 2013). Trust can be conceptualised as an aspect of a relationship which varies within a person and across relationships, where ability, benevolence and integrity contribute to building trust in a group or organisation (Schoorman et al., 2007). It can also be analysed as a belief, as a decision and as an action (Dietz \& Den Hartog, 2006). Beliefs are subjective probabilities, where performing a behaviour leads to a certain outcome (Fishbein \& Ajzen, 2010). Therefore, trust is defined in this study as a set of beliefs that influence decisions and precede behavioural outcomes.

While trust can be considered personal to individuals, within an organisation, several individuals may hold more or less similar beliefs. Organisational trust may be formed when such similar beliefs are shared to a large extent. Therefore, organisational trust may alter employees' collective perception regarding the trustworthiness of their organisation, which may in turn influence employees' behaviour. Consequently, organisational trust may reflect the culture or climate within an organisation, where high levels of trust are related to positive expectations of the 
intents and behaviour of the organisation (Shockley-Zalabak et al., 2000). Researchers have suggested that organisations with high levels of internal trust will be more successful, adaptive and innovative, and they will contribute to employee satisfactions and organisational commitment (Flaherty \& Pappas, 2000; Shockley-Zalabak et al., 2000). Organisational trust is also relevant to OCBs and reductions in CWBs.

Organisational justice is often associated with trust within the settings of organisational change. Procedural justice is particularly relevant to this study because it is seen when individuals are willing to give up control in the final decision-making stage if it is perceived that they had control over the procedures that reached the final decision (Thibaut \& Walker, 1975). This has clear relevance because the outcome of downsizing and early retirement following a merger was believed to be outside of the employees' control; there was no transparent employee consultation before the criteria for early retirement were finalised, announced and executed.

\section{Present Study and Methods}

This case study focused on the recent merger between two large Norwegian oil companies, Statoil and Hydro Oil $\&$ Gas. The merger was expected to promote future growth; therefore, a workforce reduction was unavoidable. The post-merger downsizing strategy deployed was a voluntary early retirement package for all employees who had attained at least 58 years of age. Both companies adhered to the mandatory retirement age of 70 years in Norway, with optional pensions after the age of 62 years. This seems counter-intuitive to the government's effort and OECD recommendations to retain older workers in the workforce to bridge the experience gaps with the younger generations while also contributing to competent workforce supply and reduced pension costs (Perspektivmeldingen, 2013; OECD, 2013). The recipients were entitled to $70 \%$ of their full salary until the actual retirement age of 67 years (StatoilHydro merger information package, 2008) and were restricted from future direct work for Statoil or Hydro. An estimated 1500 employees took the package, which was about $5 \%$ of all employees and $90 \%$ of all targeted employees (Statoil Hydro, 2007). The offer was presented only to Norwegians and/or individuals with Norwegian home based contracts (i.e., expatriates on Norwegian contract but working in a subsidiary or foreigners on Norwegian contract).

This study provides an empirical case to study possible organisational injustice experiences when a lucrative early retirement was not offered to all the eligible, by age, employees. The case builds on the premise that the early retirement offer violated one of the core principles of fairness, focusing on the consistencies in the processes and treatments. At the outset, employees who lost their jobs may be perceived as victims; however, the early retirement package was a lucrative one, and the employees leaving the organisation were regarded highly for their knowledge within the petroleum-related labour market. Many of them found paid jobs after this 'early retirement.'

A single case study design was chosen because this study aims to reveal insights into a phenomenon (Yin, 1994) and demonstrate "... a causal argument about how general social forces shape and produce results in particular settings" (Walton, 1992, p. 122). The data were collected using semi-structured face-to-face interviews. In this study, employees from the identified three international regions, Asia, UK and the US, who were either eligible or not eligible for the early retirement package and were employed during the time of the merger, were invited to participate in the study. A total of 28 interviews were conducted. All interviewees were employed at the time of the merger and hence, were classified as 'downsizing survivors.'

A semi-structured interview guide was developed based on the research question to ensure consistency. The main topics of discussion included (a) initial reactions to the downsizing strategy and assessment of the ways in which respondents found out about the early retirement and content of the package, (b) their perceptions of the effects of the early retirement package and (c) individual psychological outcomes. The research focused on the individual experiences of the post-merger early retirement package as a whole, without actively seeking responses relating to organisational justice to augment the validity of the research. Therefore, the semi-structured interviews explored the general views from the locations outside the headquarters' perspective and directed the interviewees to elaborate on their experiences. The self-categorisation question asked all interviewees to choose three emotion-descriptive words to summarise their perceptions of the situation.

Construction of the interview questions was challenging because previous research has pointed out that independence of procedural and distributive justice is questionable (Folger, 1987; Sweeney \& McFarlin, 1997). Some studies have revealed high correlations between the two justice dimensions, meaning that they may not be distinctive in the minds of many people. Thibaut and Walker (1975) and Colquitt et al. (2001) argued that procedural evaluations are based in large part on the outcomes obtained and that the same event can be seen as a process in one context and interpreted as an outcome in other contexts. For example, in this case study, the early retirement package can be seen as an outcome of downsizing or as the process for head count reduction. Without 
such clarifications, the researcher faced the risk of being unable to fully explore and separate the dimensions when conducting data analyses. However, the studies that found such high correlations are almost exclusively quantitative, prompting the needs for studies like the current one, which applies qualitative analyses of these dimensions. It became evident throughout the interview process that the early retirement package was viewed from both procedural and outcome perspectives, and it was a recurring theme when trust and turnover intent were discussed.

Self-reporting has long been common modes of measurement for CWB researchers (Berry et al., 2012; Fox, Spector, Goh, \& Bruursema, 2007) because many CWBs are relatively covert behaviours in which employees engage in with the intention of not getting caught. Only employees themselves have complete knowledge of their engagement in CWB. This study assessed self-reporting of CWBs using the question, "Do/Did you work differently, in any ways, after knowing what is going on in the headquarters?" Furthermore, from a research ethics perspective, having employees anonymously report their own CWBs circumvents some ethical concerns associated with supervisor or co-worker reports (Fox \& Spector, 1999). Such reports draw attention to employees' negative organisational behaviours by asking their supervisors or co-workers to rate the employees' CWB, which could have negative consequences for the employees, calling into question whether risk is adequately minimised.

Narrative analyses were utilized in the organisation, and the interview data were analysed through coding and developing category systems. This research sought to achieve internal validity through triangulation by using multiple sources of data (Yin, 1994), such as interviews and documentation analysis. To ensure reliability, a thorough documentation of procedures was produced and adhered to during the interviews and throughout data recording and analyses.

\section{Results}

The results indicated that injustice was certainly perceived by the interviewees. A summary of results is represented in Figure 1. The results indicate that perceived organisational injustice does not always lead to expected CWBs. It was found that to a large degree, learnt helplessness provided buffering effects against expected CWBs. The study also suggests that organisational culture and trust are powerful antecedents to learnt helplessness.

The self-categorisation question asked all interviewees to choose three descriptive words to describe their emotions regarding the situation. Clear themes emerged from the interviews, with words relating to acceptance, shock/annoyance and envy being most frequently cited.

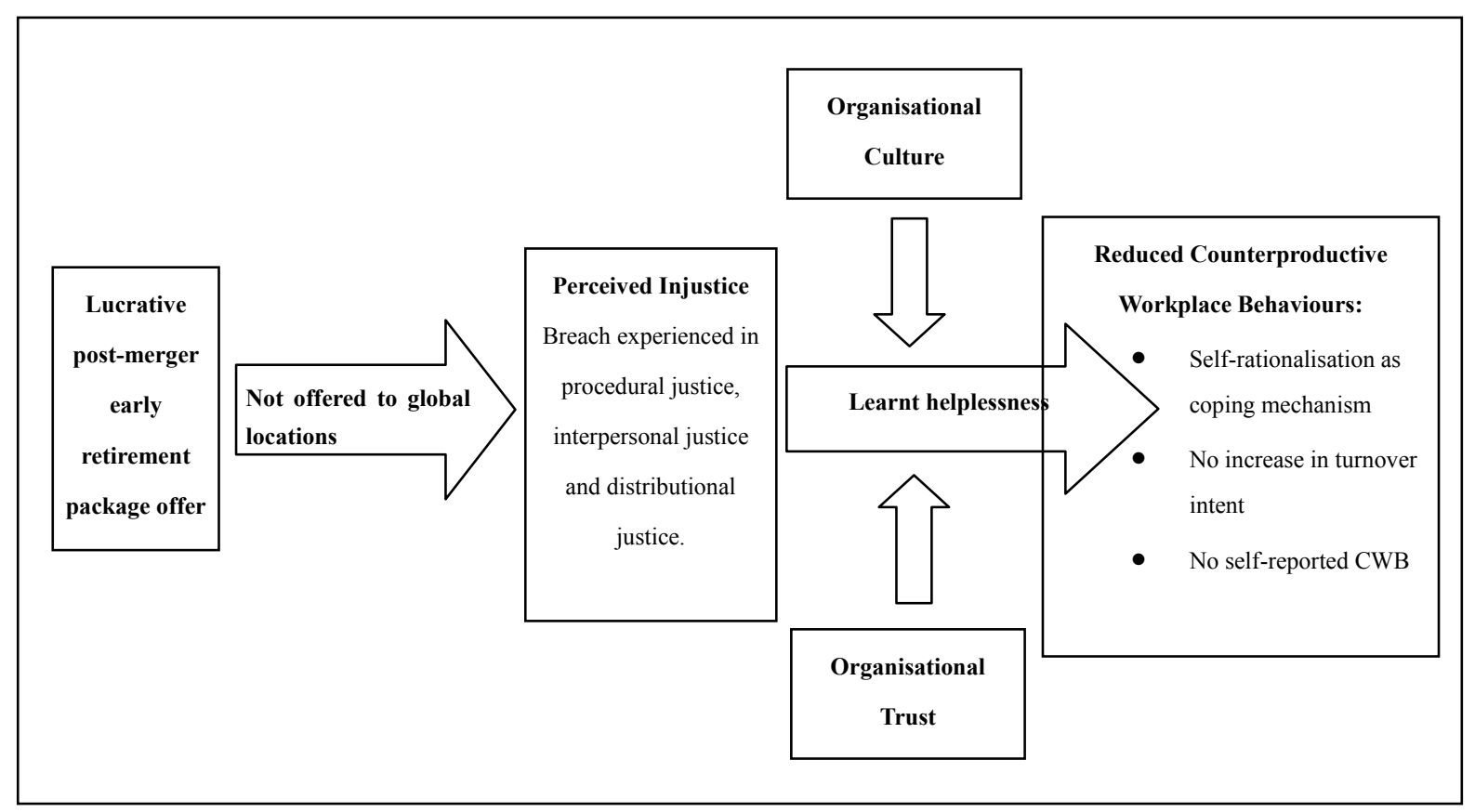

Figure 1. Summary of results: Learnt Helplessness as a buffer to counterproductive work behaviours 


\subsection{Three Justice Perspectives}

Distributive justice was mentioned multiple times in various interviews, because many of the respondents expressed concerns in the initial phase when they found out about the early retirement package and that it would be offered only to the Norwegian organisation.

Why were we not offered the same opportunity? (UK, US)

I know that for a site of 60 , we may not be able to make much of the difference from total headcount, but it would have been nice, for once, to be considered part of the big company. (Asia)

All respondents in the initial phase of the interview expressed that because the early retirement package was not offered at their locations, they perceived a form of injustice. This was evident from their responses to the straightforward question, "Do you think the early retirement package should have been offered to everyone that were eligible by age and not just in Norway?" However, as the research interview moved forward, it became evident that although individuals perceived injustice, they were able to provide self-justification for why they were not offered the packages. The self-justification heightened the individuals' sense of learnt helplessness, which in turn reduced CWB outcomes so that individuals felt no need to exert CWBs to even out the sense of organisational injustice.

One respondent, a 59-year-old department head, expressed:

Unlike Norway, people here struggle to save for retirement. I would no doubt take the package if it were offered to me. It is a shame that it was not. I would have loved to retire with all that money coming. (Asia)

From the procedural justice perspective, it was evident that the employment relations' model exerted large influence.

Norway has the strong union relationship, which we don't have here. The company policies of involving unions don't apply here. (Asia)

Legally, we are not part of the same company, as we are subsidiaries and separate legal entities. We are not governed by the same laws. (US)

Furthermore, interviewees commented on the procedures used to arrive to the downsize decision:

What I don't understand is how they chose the people to be laid off? Why 58? Why not 55? Why not 60 ? Why not by merit or experiences? (UK)

One interviewee candidly said:

I bet we paid some smart and expensive management consultant to come up with this silly way of downsizing. (UK)

Interactional justice was clearly evident when individuals were asked about how the subsidiaries learned about the early retirement package. All interviewees indicated that they learned about it through word-of-mouth from their Norwegian colleagues or from other subsidiaries. The significance of the response was that none of the respondents recalled any official communication, although all respondents recognised that because they were not the target audience, it was 'reasonable' that such information was not disclosed.

One respondent, a 47-year-old in Business Development, expressed that information sharing was Inconsistent at best. (UK)

Another described the process of finding out the early retirement downsize was almost like:

- an ambush of information. First, we were told there would be a merger. Then we found out they were going to get rid of all the employees over the age of 58 ! (UK, US)

One employee based in the UK remembered that he read the package offer on the intranet and later heard from the Norwegian expatriate colleagues who were entitled to receive the package but not from the local employees.

The results also provide evidence to support the structural determinant of justice. Being part of a knowledge-based and ageing workforce provoked a sense of injustice even for those who remained in the organisation; these individuals interpreted that the treatment of those being downsized violated the sense of individuals' knowledge and worth.

I was surprised that they picked the most experienced staff to get rid of. So much of that knowledge will be lost! (US)

They must feel like their experiences are worthless in the new post-merger company and that is why they 
will pay for them to leave. (Asia)

Ageing is not a sickness to be rid of... (UK)

When asked to describe the organisation's attempt to manage knowledge before, during or after the merger, none of the respondents was able to pinpoint a deliberate and organised process initiated by the organisation to manage the exiting knowledge of the voluntary early retirees.

Moreover, many participants expressed a general sense of concern about the message of the downsize strategy at a broader industry level because the company is considered to be the largest employer in Norway.

I am sure many other companies out there will be happy to have these people in with big . (US)

The competencies lost must be well regarded (and paid) in the market. (UK)

This is further exemplified by the delays in internal projects; more than $20 \%$ of the core project members took the early retirement package and left the company.

\subsection{Leant Helplessness and Self-Justification}

Learnt helplessness can be clearly identified through the respondents' self-justification of the situation. When asking the participants about their perceptions of why the early retirement package was not offered to the international locations, most responses reflected perceived injustice of the situation, followed by self-justification or learnt optimism, as suggested by Seligman (1975; 1992). Self-justifications also carried an innate sense of choice.

At the end of the day, I know I can't change anything [injustice perception], but I am happy to still have a job [self-justification]. The company is not bad at all. So it is business as usual. (UK)

I am about to retire in a few years, and it would be nice to be included in the package [injustice perception]. But if I wanted to be treated like the Norwegians, I would have to live and work in Norway. The tax they pay is crazy! [self-justification]. (Asia)

It was kind of uncomfortable at the start to think about how the rest [of the Norwegians] got the better deal [injustice perception], but for the rest, I am pretty happy with the company and the culture, this should not affect how I work in the future [self-justification]. (US)

More significantly, the interviewees appeared calm, retrospective, and almost nonchalant. This is relevant because learnt helplessness can be exemplified by the contentment of the perceived negative situation, which is expressed through a less emotional tone of voice, as observed in other interviews within the research.

All respondents mentioned explicitly, in a self-justified manner, that organisational culture, structure and policies were the reasons why they accepted the fact that the lucrative early retirement package was not offered to them and/or their colleagues.

At the end of the day, I know I can't change anything. It has always been the way; the Ivory tower makes a decision that is tailored for the Norwegians. (UK)

Norway has the strong union relationship, which we don't have here. The company policies of involving unions don't apply here. There is no one to fight for us. (Asia)

It was kind of uncomfortable at the start to think about how the rest [of the Norwegians] got the better deal. This has always been the case, so I am not surprised it is the case with the merger. (US)

\subsection{Antecedents of Learnt Helplessness: Organisational Culture and Trust}

Self-justification in the nature of trust was a recurring theme when individuals were prompted to elaborate on what they had done as a reaction to the perceived organisational injustice and why. The respondents all reported that they chose to move forward without retaliating in response to the situation, with no reported increase in turnover intent or negative organisational citizenship behaviours.

I think the company knows what it is doing. It must have a lay-off target to reach, and this is the way it has chosen to reach it. (UK)

This is the biggest company in Norway! This must be the best option given the situation. Although I wonder if the management has thought through it. (US)

I am sure this will not happen again, and the company did not do it on purpose to rip us off. (Asia)

Although organisational trust was observed, another reoccurring theme revolved around interviewees' interpretation of the highly published company values: Open, Hands-on, Courage and Caring (Statoil official 
website, 2014). Because Statoil explicitly emphasized these values as the foundation of performance management, many interviewees expressed with sarcasm that the company hardly follows the quoted values. For instance, interviewees would pose a rhetorical question to the interviewer, for example:

By not offering the package to all location, is this truly being 'Open' and 'Caring'? (Asia)

All locations mentioned the explicit promotion of the company's values post-merger and the ways in which it conflicted with the downsizing. The interviewees talked about how the values where introduced as part of performance management and were posted around the offices as posters and table cards.

\subsection{Consequences: No Evidence of Predicted CWB}

All interviewees indicated that they decided to continue working the same way without engaging in negative organisational behaviours.

I just went about doing my job as usual and forget about this. (Asia)

Other than this, other company do not offer the same culture and environment. I am not going to jeopardise my work. (UK)

Better to have a job than nothing. Not going to quit or do something 'funny' over this. (US)

With such injustice, it is likely that there may be an increase in turnover and some self-reported CWBs in an attempt to balance out the injustice. However, no locations have observed heightened turnover rates.

Archival documentations also suggest no cases of disciplinary actions towards CWBs.

\section{Discussion}

Clearly, the lucrative early retirement package given only to employees at the Norwegian head offices evoked perceptions of injustice among employees at international locations. However, minimal CWBs or reduced OCBs were observed in this case study. We observed a buffering effect of learnt helplessness against the predicted CWBs in this case of organisational injustice. To reiterate, buffering reflects a capacity to absorb system shocks, bounce back, heal relationships, and provide a form of resilience in organisations (Sutcliffe \& Vogus, 2003). In this case, workers absorbed the shock of downsizing and an early retirement package not offered to all employees across all subsidiaries that meets the eligible age of 58 .

Most interviews integrated Seligman's (1975) theory of learnt helplessness. The interviews started with the description of the perceived injustice of the situations, followed by a self-justification or learnt optimism statement. The interviewees started by stating that offering the lucrative package was an injustice, and then they justified the company's decision using phrases such as 'this is always the case.' These results support the notion that learnt helplessness theory can be used to understand employees' behaviours and feelings when dealing with undesirable organisational situations. In this case, the employees also found reasons, such as union strength for employee representation in subsidiaries, Norwegian tax regimes, the Norwegian-dominated organisational culture and policies, as self-justification to mitigate the perceived organisational injustice.

To elaborate on Seligman's (1975) suggestion that learnt helplessness is manifested in individuals who have given up the belief that they can escape from undesirable situations and have developed alternative and passive coping strategies instead; this study suggests a more complicated manifestation. It suggests that the coping mechanism one chooses in an employment situation is associated with the ability to regain a feeling of control and thus have a choice. By revisiting the quotes from the interviewees, all statements referred to some kind of choice. The self-justification of choice is that the company is still considered a good company, and it is the individual's choice to remain with the organisation and disallow the situation to influence their work deliveries and behaviours. The self-justification was also reflected in the participants' statements that it was their choice not to be a Norwegian, yet choosing to work for a Norwegian company.

Learnt helplessness has a buffering effect against predicted OCBs by weakening the predicted level of OCB that can be exerted when organisational injustice is experienced. This contrasted with previous research, in which organisational injustice perceptions ultimately led to negative organisational outcomes, such as increases in turnover intent, decreases in loyalty, decreases in productivity and increases in CWBs or reduced OCBs (Appelbaum, 1997; Berry et al., 2012; Simons \& Roberson, 2003). This study indicated that learnt helplessness absorbed the shock of organisational injustice and weakened CWBs, resulting in no distinctive increases in turnover or self-reported CWBs. This study design and method pointed out the weaknesses of other studies that may not have assessed the causal effects of the observed relationships.

The interviewees expressed an overwhelming organisational trust in the company. Through their responses, 
learnt optimism was observed; almost all the interviewees stated that after all, they felt it was a good company to work for, despite the current perceived injustice. The sense of current is important, because self-justification also suggests that this is only a current situation, the perceived injustice will pass and the justice will be restored or felt again. In other words, individuals trust the organisation enough to believe this situation will soon pass, and they are not planning a deliberate effort with negative intentions. In this respect, the sense of current raises a question about whether one will react less negatively to a perceived organisational injustice if it is perceived as a first or one-off situation or less negatively to perceived organisational injustice simply because they are used to it, leading to learnt helplessness. In this case, organisational values and trust seem to be ingrained in the organisation, and such perceived injustice leads to self-justification of learnt helplessness. Trust is often related to the notion of $\mathrm{OCB}$, defined as behaviours that are discretionary and extra-role and contribute positively to the functioning of the organisation, which is not directly or explicitly recognised by the formal reward system (Organ, 1988). Considering the interpretations of OCB, this case suggests that learnt helplessness can be interpreted as a manifestation of OCB because it allows the organisation to function with business as usual even during the significant times of merger and post-merger. The study supports previous research, showing that members of an organisation often translate and perceive the treatment of one group of employees as a collective representation of the organisation, even though the actions were not directly aimed toward themselves (Hopkins $\&$ Weathington, 2006).

However, we cannot make a definite conclusion relating to time as a buffer. It also does not determine whether the buffering effect against CWBs is permanent or something that can be unlearnt. Employees perceived that this violation of organisational justice was a single event, making it current, and thus buffering against CWBs may be temporary.

\section{Limitations and Future Research Implications}

Because the data were collected through self-reporting, some individuals may have reported an exaggerated sense of injustice or underreported negative organisational behaviour because they feared negative repercussions. It would be particularly interesting to see whether the lack of effect on CWBs can be supported through quantitative methodologies, such as monitoring performance and unit work outputs.

Further studies on the antecedents of learnt helplessness may also be relevant when including organisational culture and trust as influential antecedents. A longitudinal approach may also reveal the possible negative and long-term effects of learnt helplessness and examine whether the buffering effects observed were permanent or temporary.

The results of the study suggest using quantitative methodologies to test the potential relationships between learnt helplessness and CWBs and to provide a framework for generalisation. However, because much research in the area is quantitative in nature, more qualitative research is recommended to explore the relationships observed in this research under various conditions. Therefore, a longitudinal study combining both qualitative and quantitative methods is recommended.

\section{Managerial Implications}

By understanding justice perspectives, organisations can be more effective when making organisational decisions and considering fairness in the execution of downsizing strategies. This study emphasizes the importance of ensuring that organisational values are aligned with organisational change management strategies and internal communication of change decisions.

\section{Conclusions}

First, this study provides an empirical case where perceived organisational injustice may not always lead to predicted negative outcomes of turnover intents and CWBs. This may be counter-intuitive and challenge the conclusions of previous research, providing an interesting backdrop to alternative outcomes.

Second, it revealed the unique buffering relationship between learnt helplessness and CWBs. This learnt helplessness may contribute to performance issues in the end, and it may buffer the negative organisational outcomes in the immediate short run. It does not suggest that organisational injustice is justifiable and without negative organisational or personal effects. It does, however, suggest that when trust is ingrained in the organisation, perceived injustice may be buffered through self-justification stemming from learnt helplessness. The study encourages organisations to consider the importance of assessing organisational culture and aligning organisational change management strategies to internal communications of such decisions.

Last, this study calls for longitudinal research to explore the examined relationships between learnt helplessness and post-merger organisational outcomes. In particular, future studies need to explore the possibilities of learning 
helplessness as a temporary buffer of predicted negative organisational outcomes.

\section{References}

Abramson, L. Y., Seligman, M. E. P., \& Teasdale, I. (1978). Learned helplessness in humans: Critique and reformulation. Journal of Abnormal Psychology, 87, 49-59. http://dx.doi.org/10.1037/0021-843X.87.1.49

Adams, J. S. (1965). Inequity in social exchange. In L. Berkowitz (Ed.), Advances in experimental social psychology (pp. 267-299). New Yourk: Academic Press.

Appelbaum, S. H. (1997). Socio-technical system theory: An intervention strategy for organisational development. Management Decisions, 35(6), 452-463. http://dx.doi.org/10.1108/00251749710173823

Appelbaum, S. H., Delage, C., Labib, N., \& Gault, G. (1997). The survivors' syndrome aftermath of downsizing. Career Development International, 2(6), 278-286. http://dx.doi.org/10.1108/13620439710178639

Appelbaum, S., \& Donia, M. (2000). The realistic downsizing preview: A management intervention in the prevention of survivor syndrome (Part 1). Career Development International, 5(7), 333-350. http://dx.doi.org/10.1108/EUM0000000005384

Argote, L., McEvily, B., \& Reagans, R. (2003). Managing knowledge in organizations: An integrative frame-work and review of emerging themes. Management Science, 49(4), 571-582. http://dx.doi.org/10.1287/mnsc.49.4.571.14424

Arshad, R., \& Sparrow, P. (2010). Downsizing and survivor reactions in Malaysia: modelling antecedents and outcomes of psychological contract violation. International Journal of Human Resource Management, 21(11), 1793-1806. http://dx.doi.org/10.1080/09585192.2010.505080

Barney, J. (1991). Firm resources and sustained competitive advantage. Journal of Management, 17(1), 99-120. http://dx.doi.org/10.1177/014920639101700108

Berry, C. M., Carpenter, N. C., \& Barratt, C. L. (2012). Do other-reports of counterproductive work behaviour provide an incremental contribution over self-reports? A meta-analytic comparison. Journal of Applied Psychology, 97(3), 613-636. http://dx.doi.org/10.1037/a0026739

Bies, R. J., \& Moag, J. S. (1986). Interactional justice: Communications criteria of fairness. In R. Lewicki \& B. Sheppard (Eds.), Research on negotiation in organizations (pp. 43-55). Greenwich, CT: JAI Press.

Brockner, J. (1988). The effects of work layoffs on survivors. Research, theory and practice. Research in Organizational Behavior, 10, 213-255.

Brockner, J., Grover, S., Reed, T., DeWitt, R., \& O’Malley, M. (1987). Survivors' reactions to layoffs: We get by with a little help for our friends. Administrative Science Quarterly, 32(4), 526-541. http://dx.doi.org/10.2307/2392882

Cascio, W. F. (2002). Strategies for responsible restructuring. Academy of Management Executive, 16(3), 80-91. http://dx.doi.org/10.5465/AME.2002.8540331

Chadwick, C., Hunter, L. W., \& Walston, S. L. (2004). Effects of downsizing practices on the performance of hospitals. Strategic Management Journal, 25(5), 405-427. http://dx.doi.org/10.1002/smj.383

Chuang, A., Judge, T. A., \& Liaw, Y. J. (2012). Transformational leadership and customer service: A moderated mediation model of negativity affectivity and emotion regulation. European Journal of Work and Organizational Psychology, 21, 28-56. http://dx.doi.org/10.1080/1359432X.2010.532911

Colquitt, J. A., Conlon, D. E., Porter, C., Wessom, M., \& Ng, K. Y. (2001). Justice at the Millennium: A meta-analytic review of 25 years of organisational justice research. Journal of Applied Psychology, 83(3), 425-445. http://dx.doi.org/10.1037/0021-9010.86.3.425

Cropanzano, R., \& Greenberg, J. (1997). Progress in Organisational justice: Tunnelling through the maze. In C. Cooper \& I. Robertson (Eds.), International review of industrial and organisational physiology (pp. 317-372). New York: Weiley.

Dietz, G., \& Den Hartog, D. (2006). Measuring trust inside organizations. Personnel Review, 35(5), 557-588. http://dx.doi.org/10.1108/00483480610682299

Dolan, S., Belout, A., \& Balkin, D. B. (2000). Downsizing without downgrading: Learning how firms manage their survivors. International Journal of Manpower, 21(1), 34-46. http://dx.doi.org/10.1108/01437720010319444 
Fishbein, M., \& Ajzen, I. (2010). Predicting and changing behaviour. The theory of reasoned action. New York: Psychology Press, Taylor \& Francis Group.

Flaherty, K., \& Pappas, J. (2000). The role of trust in salesperson-sales manager relationships. Journal of Personal Selling and Sales Management, 20, 271-278.

Folger, R. (1987). Reformulating the preconditions of resentment: A referent cognitions model. In J. Masters \& W. Smith (Eds.), Social comparison, social justice, and relative deprivation: Theoretical, empirical, and policy perspectives (pp. 183-215). Erlbaum, Hillsdale: NJ.

Folger, R., \& Konovsky, M. A. (1989). Effects of procedural and distributive justice on reactions to pay raise decisions. The Academy of Management Journal, 32(1), 115-130. http://dx.doi.org/10.2307/256422

Fontaine, R., \& Oziev, G. (2013). Developing self-awareness among students: An Islamic perspective. European Scientific Journal, 1, 409-417.

Fox, S., \& Spector, P. E. (1999). A model of work frustration-aggression. Journal of Organizational Behavior, 20(6), 915-931. http://dx.doi.org/10.1002/(SICI)1099-1379(199911)20:6<915::AID-JOB918>3.0.CO;2-6

Fox, S., Spector, P. E., Goh, A., \& Bruursema, K. (2007). Does your coworker know what you're doing? Convergence of self- and peerreports of counterproductive work behavior. International Journal of Stress Management, 14(1), 41-60. http://dx.doi.org/10.1037/1072-5245.14.1.41

Freeman, S. J., \& Cameron, K. S. (1993). Organizational downsizing: A convergence and reorientation framework. Organization Science, 4(1), 10-29. http://dx.doi.org/10.1287/orsc.4.1.10

Furnham, A., \& Siegel, E. (2012). Reactions to organisational injustice: Counter work behaviors and the insider threat. In E. Kals \& J. Maes (Eds.), Justice and conflicts (pp. 199-217). Berlin Heidelberg: Springer.

Gordon, M. E., \& Fryxell, G. E. (1993). The role of interpersonal justice in organizational grievance systems. In R. Cropanzano (Ed.), Justice in the workplace: Approaching fairness in human resources management (pp. 231-255). Hillsdale, NJ, England: Lawrence Erlbaum Associates, Inc

Greenberg, J. (1987). A taxonomy of organisational justice theory. Academy of Management Review, 12(1), 9-22.

Greenberg, J. (1993). The social side of fairness: Interpersonal and informational classes of organizational justice. In R. Cropanzano (Ed.), Justice in the workplace: Approaching fairness in human resource management (pp. 79-103). Hillsdale, NJ: Lawrence Erlbaum.

Greenberg, J., \& Baron, R. A. (2003). Behaviour in organizations. Upper Saddle River, NJ: Pearson Education.

Gutknecht, J., \& Keys, J. (1993). Mergers, acquisitions and takeovers: Maintaining morale of survivors and protecting employees. The Academy of Management Executive, 7(3), 26-36.

Heider, F. (1958). The psychology of interpersonal relations. New York: Weiley. http://dx.doi.org/10.1037/10628-000

Hollinger, R. C., \& Clark, J. C. (1982). Formal and informal social control of deviance. The Sociological Quarterly, 23, 333-343. http://dx.doi.org/10.1111/j.1533-8525.1982.tb01016.x

Hopkins, S. M., \& Weathington, B. L. (2006). The relationship between justice perceptions, trust, and employee attitudes in a downsizing organisation. Journal of Psychology, 140, 477-498. http://dx.doi.org/10.3200/JRLP.140.5.477-498

Kernan, M., \& Hanges, P. (2002). Survivor reactions to reorganisations: Antecedents and consequences of procedural, interpersonal and informational justice. Journal of Applied Psychology. 87(5). 916-928. http://dx.doi.org/10.1037/0021-9010.87.5.916

Kim, U., Triandis, H. C., Kfiitibai, C., Choi, S. C., \& Yoon, G. (1994). Individualism and collectivism: Theory, method, and applications. Thousand Oaks, CA: Sage.

Kundi, G., Javed, A., \& Khan, M. (2013). To measure the attitudes of organisation members in managing stress during work hours. Journal of Economics and Sustainable Development, 4(8), 216-230.

Leventhal, G. S. (1980). What should be done with equity theory? New approaches to the study of fairness in social relationships. In K. Gergen, M. Greenberg, \& R. Willis (Eds.), Social exchange: Advances in theory and research (pp. 27-55). New York: Plenum Press. http://dx.doi.org/10.1007/978-1-4613-3087-5_2

Mason, L., Boscolo, P., Tornatora, M. C., \& Ronconi, L. (2013). Besides knowledge: A cross-sectional study on the relations between epistemic beliefs, achievement goals, self-beliefs, and achievement in science. 
Instructional Science, 41(1), 49-79. http://dx.doi.org/10.1007/s11251-012-9210-0

Moorman, R. H. (1991). Relationship between organisational justice and organisational citizenship behaviours: Do fairness perception influence employee citizenship? Journal of Applied Psychology, 76(6), 845-855. $\mathrm{http} / / / \mathrm{dx}$.doi.org/10.1037/0021-9010.76.6.845

Noer, D. (1993). Healing the wounds: Overcoming the trauma of layoffs and revitalizing downsized organizations. San Francisco: Jossey-Bass.

OECD. (2013). Ageing and Employment Policies: Norway 2013: Working Better with Age. OECD Publishing. http://dx.doi.org/10.1787/9789264201484-en

Organ, D. W. (1988). Organizational citizenship behavior: The good soldier syndrome. Lexington, MA: Lexington Books.

Organ, D. W. (1990). The motivational basis of organizational citizenship behaviour. In B. M. Staw \& L. L. Cummings (Eds.), Research in organizational behaviour (pp. 43-72). Greenwich, CT: JAI Press.

Organ, D. W., \& Moorman, R. H. (1993). Fairness and organizational citizenship behaviour: What are the connections? Social Justice Research, 6, 5-18. http://dx.doi.org/10.1007/BF01048730

Organ, D. W., \& Paine, J. B. (1999). A new kind of performance for industrial and organisational psychology: Recent contributions to the study of organisational citizenship behaviour. International Review of Industrial and Organisational Psychology, 14, 337-368.

Østhus, S., \& Mastekaasa, A. (2010). The impact of downsizing on remaining workers' sickness absence. Social Science \& Medicine, 71(8), 1455-1462. http://dx.doi.org/10.1016/j.socscimed.2010.06.045

Oziev, G., \& Fontaine, R. (2013). The concept of scarcity: An Islamic perspective. Malaysian Management Review, 46(1), 27-40.

Perspektivmeldingen. (2013). Meld. St. 12 (2012-2013) (White paper on future economical perspectives for Norway). Oslo: Ministry of Finance.

Proulx, T., Inzlicht, M., \& Harmon-Jones, E. (2012). Understanding all inconsistency compensation as a palliative response to violated expectations. Trends in Cognitive Science, 16(5), 285-291. http://dx.doi.org/10.1016/j.tics.2012.04.002

Ranft, V. A., \& Ranft, A. L. (1999). Rightsizing the multi-divisional firm: Individual response to change across divisions. Managment: Special Issue: Organisational Downsizing, 1(3), 195-208.

Rehman, W., \& Naeem, H. (2012). The impact of downsizing on the performance of survived employees: A case study of Pakistan. African Journal of Business Management, 6(7), 2429-2434.

Robinson, S. L., \& Bennett, R. J. (1995). A typology of deviant workplace behaviours: A multidimensional scaling study. Academy of Management Journal, 38(2), 555-572. http://dx.doi.org/10.2307/256693

Saxena, S., \& Shah, H. (2008). Effect of organisational culture on creating learned helplessness attributions in R\&D professionals: A canonical correlation analysis. Vikalpa, 33(2), 25-45.

Schmitt, A., Borzillo, S., \& Probst, G. (2011). Don’t let knowledge walk away: Knowledge retention during employee downsizing. Management Learning, 43(1), 53-74. http://dx.doi.org/10.1177/1350507611411630

Schoorman, F. D., Mayer, R. C., \& Davis, J. H. (2007). An integrative model of organisational trust: Past, present and future. Academy of Management Review, 32, 344-354. http://dx.doi.org/10.5465/AMR.2007.24348410

Seligman, M. (1992). Helplessness: On depression, development and death. New York: Freeman.

Seligman, M. E. P. (1975). Helplessness. Annual Review of Medicine, 23, 407-412. http://dx.doi.org/10.1146/annurev.me.23.020172.002203

Shockley-Zalabak, P., Ellis, K., \& Winograd, G. (2000). Organizational trust: What it means, why it matters. Organisational Development Journal, 18, 35-48.

Silvet, J. (2013). Learned helplessness during organisational change. Versita, 60(2), 1-11.

Simons, T., \& Roberson, Q. (2003). Why managers should care about fairness: The effect of aggregate justice perceptions on organizational outcomes. Journal of Applied Psychology, 88, 432-443. http://dx.doi.org/10.1037/0021-9010.88.3.432

Smith, C. A., Organ, D., \& Near, J. P. (1983). Organisational citizenship behaviour: Its nature and antecedents. Journal of Applied Psychology, 68, 653-663. 
Spector, P., Fox, S., Penney, L. Bruursema, K., Goh, A., \& Kessler, S. (2005). The dimensionality of counterproductivity: Are all counterproductive behaviours created equal? Journal of Vocational Behaviour, $68,446-460$.

Statoil Official Company Website. (2014). $\quad$ Retrieved from http://www.statoil.com/en/about/ethicsvalues/pages/default.aspx

Statoil, H. (2007). Statoil Hydro merger information package.

Staw, B. M. (1976). Knee-deep in the big muddy: A study of escalating commitment to a chosen course of action. $\begin{array}{lllll}\text { Organisational Behaviour and Human Performance, } & \text { 16, }\end{array}$ http://dx.doi.org/10.1016/0030-5073(76)90005-2

Sutcliffe, K. M., \& Vogus, T. J. (2003). Organizing for resilience. In K. S. Cameron, J. E. Dutton, \& R. E. Quinn (Eds.), Positive organizational scholarship: Foundations of a new discipline (pp. 94-110). San Francisco: Berrett Koehler.

Sweeney, P. D., \& McFarlin, D. B. (1997). Process and outcomes: Gender differences in the assessment of $\begin{array}{lllll}\text { justice. Journal of } & \text { Organisational }\end{array}$ http://dx.doi.org/10.1002/(SICI)1099-1379(199701)18:1<83::AID-JOB779>3.0.CO;2-3

Thibaut, J., \& Walker, L. (1975). Procedural justice: A psychological analysis. NJ: Erlbaum, Hillsdale.

Walton, J. (1992). Making the theoretical case. In C. C. Ragin \& H. S. Becker (Eds.), What is a Case: Exploring the foundations of social inquiry (pp. 121-137). Cambridge: Cambridge University Press.

Wilkinson, A. (2005). Downsizing, rightsizing, or dumbsizing? Quality, human resources and the management of $\begin{array}{lllll}\text { sustainability. Total } & \text { Quality } & \text { Management, } & 16(8-9), & 1079-1088 .\end{array}$ http://dx.doi.org/10.1080/14783360500163326

Yin, R. (1994). Case study research: Design and methods. Thousand Oaks, CA: Sage,

\section{Copyrights}

Copyright for this article is retained by the author(s), with first publication rights granted to the journal.

This is an open-access article distributed under the terms and conditions of the Creative Commons Attribution license (http://creativecommons.org/licenses/by/3.0/). 